\title{
Biological activity of lactoferrin-functionalized biomimetic hydroxyapatite nanocrystals
}

\author{
This article was published in the following Dove Press journal: \\ International Journal of Nanomedicine \\ 5 March 2014 \\ Number of times this article has been viewed
}

\author{
Nunzia Nocerino' \\ Andrea Fulgione' \\ Marco lannaccone' \\ Laura Tomasetta' \\ Flora lanniello' \\ Francesca Martora' \\ Marco Lelli ${ }^{2}$ \\ Norberto Roveri ${ }^{2}$ \\ Federico Capuano ${ }^{3}$ \\ Rosanna Capparelli ${ }^{1}$ \\ 'Department of Agriculture Special \\ Biotechnology Center Federico II, \\ CeBIOTEC Biotechnology, \\ University of Naples Federico II, \\ Naples, ${ }^{2}$ Department of Chemistry, \\ G Ciamician, Alma Mater Studiorum, \\ University of Bologna, Bologna, \\ ${ }^{3}$ Department of Food Inspection IZS \\ ME, Naples, Italy
}

\begin{abstract}
The emergence of bacterial strains resistant to antibiotics is a general public health problem. Progress in developing new molecules with antimicrobial properties has been made. In this study, we evaluated the biological activity of a hybrid nanocomposite composed of synthetic biomimetic hydroxyapatite surface-functionalized by lactoferrin (LF-HA). We evaluated the antimicrobial, anti-inflammatory, and antioxidant properties of LF-HA and found that the composite was active against both Gram-positive and Gram-negative bacteria, and that it modulated proinflammatory and anti-inflammatory responses and enhanced antioxidant properties as compared with LF alone. These results indicate the possibility of using LF-HA as an antimicrobial system and biomimetic hydroxyapatite as a candidate for innovative biomedical applications.
\end{abstract}

Keywords: lactoferrin, hydroxyapatite nanocrystals, biomimetism, biological activity, drug delivery

\section{Introduction}

The widespread use of antibiotics has generated bacterial strains resistant to multiple antibiotics, sometimes resulting in very low therapeutic efficiency. For this reason, the demand for new antibiotics has been constant for almost 10 years. ${ }^{1}$ Antimicrobial peptides or proteins represent a source of "natural antibiotics", and have been found in a wide range of organisms (bacteria, plants, insects, amphibians, and mammals) where they play an important role in defense..$^{2-6}$ Lactoferrin (LF) is an antimicrobial protein that was first identified in bovine milk and later in neutrophil granules, as well as in mucosal secretions, such as saliva and the nasal and bronchial secretions of various mammalian species, including man, goat, horse, and rodents. ${ }^{7,8} \mathrm{LF}$ is a nonheme glycoprotein with a molecular weight of about $80 \mathrm{kDa}$ and is a part of the transferrin protein family, so is one of the proteins capable of binding and transferrin $\mathrm{Fe}^{3+}$ ions in serum. LF has good iron-binding affinity and is the only transferrin with the ability to retain this metal over a wide $\mathrm{pH}$ range. ${ }^{9,10} \mathrm{LF}$ also exhibits good resistance to proteolysis by trypsin and trypsin-like enzymes, and the level of resistance is proportional to the degree of iron saturation. At physiological $\mathrm{pH}$, the LF molecule has a net positive charge and its distribution in various tissues makes it a multifunctional protein. LF is involved in several physiological functions, including regulation of iron absorption in the bowel, the immune response, participation in antioxidant, anticarcinogenic, and anti-inflammatory activity, and antimicrobial infection. ${ }^{7}$
Correspondence: Rosanna Capparelli Department of Agriculture Special Biotechnology Center Federico II, CeBIOTEC Biotechnology, University of Naples, Federico II, Via Università I00, Portici 80055, Naples, Italy

Tel +3908 12539274

Fax +390817762886

Email capparel@unina.it 
The antimicrobial activity of LF is mostly due to two mechanisms. The first is the ability of LF to chelate iron with the microorganisms that require this metal, thereby depriving them of the source of this nutrient. ${ }^{11}$ The second mechanism is related to the ability of LF to interact with the cell membrane on some bacteria, leading to changes in permeability and causing lysis, with the release of lipopolysaccharide from the outer membrane of Gram-negative bacteria. ${ }^{7}$ It has been shown that LF can be synthesized de novo during certain bacterial infections, and this finding supports the idea that LF has an important role in defending its host; in fact, LF can act via iron deprivation or direct antimicrobial activity. ${ }^{8,12}$ Thermal analysis characterization of LF has been well reported in the literature, ${ }^{13,14}$ demonstrating that iron bound to LF confers more resistance to thermal denaturation, as well as to proteolytic protein digestion.

Interaction between proteins and different kinds of inorganic surfaces, like hydroxyapatite (HA) nanocrystals, biogenic silica, carbonates, and phosphate, plays an important role in many applications, including medicine, pharmacy, nanodevices, biosensors, and bioengineering. ${ }^{15,16}$ Interesting research results concern the interaction with myoglobin or alendronate bioconjugates to check the ability of an inorganic biomaterial as a carrier for bioactive molecules and drugs. Biomimetic materials appear to be function mainly as drug delivery agents. ${ }^{17}$

Biomimetic HA crystals can be synthesized as nonstoichiometric carbonated HA crystals with a length of about $100 \mathrm{~nm}$, a width of 20-30 nm, and a thickness of 3-6 nm, resembling the nanoscale-dimensioned plate-shaped morphology of bone crystals. Biomimetic HA crystals need to be synthesized in nanoscale dimensions, but with specific physicochemical properties, including a plate-shaped morphology, a low degree of crystallinity, a nonstoichiometric composition, surface crystalline disorder, and presence of carbonate ions in the crystal lattice. It is well known that HA shows a high affinity for proteins and a wide variety of biological molecules; for example, HA is widely used for the separation of various proteins in high performance liquid chromatography systems. ${ }^{18,19} \mathrm{LF}$ is adsorbed onto biomimetic HA nanocrystals at two different $\mathrm{pH}$ values (7.4 and 9.0). The positive electrostatic surface potential of LF at $\mathrm{pH} 7.4$ allows strong surface interaction with the slightly negative HA nanocrystals and avoids protein-protein interaction, leading to formation of a coating protein monolayer. The nanosized HA does not appreciably affect the conformation of the adsorbed protein. Using Fourier transform-Raman and Fourier transform infrared (FT-IR), we found that, after adsorption, the protein was only slightly unfolded with a small fraction of the alpha-helix structure being converted into turn, while the beta-sheet content remained almost unchanged. The bioactive surface of HA functionalized with LF could be utilized to improve the material performance towards the biological environment for biomedical applications. $^{20-22}$

A main challenge for innovative materials is the use of biomimetic HA nanocrystals surface-functionalized with bioactive molecules which can transfer information and operate specifically in the biological environment. In this work, we evaluated the biological activity and properties of biomimetic HA nanocrystals surface-functionalized with lactoferrin (LF-HA). This molecule shows good antimicrobial, immunomodulatory, and antioxidant properties, and our results indicate that LF-HA is an excellent candidate for overcoming antibiotic resistance.

\section{Materials and methods Preparation of biomimetic HA nanocrystals}

Biomimetic HA $\left[\mathrm{Ca}_{5}\left(\mathrm{PO}_{4}\right)_{3}(\mathrm{OH})\right]$ nanocrystals were synthesized according to a previously reported method. ${ }^{23}$ Biomimetic HA nanocrystals were precipitated from an aqueous solution of $\left(\mathrm{CH}_{3} \mathrm{COO}\right)_{2} \mathrm{Ca}(75 \mathrm{mM})$ by slow addition (one drop per second) of an aqueous solution of $\mathrm{H}_{3} \mathrm{PO}_{4}$ $(50 \mathrm{mM})$, keeping the $\mathrm{pH}$ constant at 10 by addition of $\left(\mathrm{NH}_{4}\right)$ $\mathrm{OH}$ solution.

\section{Adsorption of LF}

LF, a 97\% pure protein fraction from cow's milk, was obtained from DMW International Ltd (Veghel, the Netherlands). All common high-purity chemical reagents were supplied by Sigma-Aldrich (St Louis, MO, USA). Ultrapure water $\left(0.22 \mathrm{mS}, 25^{\circ} \mathrm{C}\right)$ was used. Samples of adsorbed lactoferrin (LF-HA) were prepared by mixing $10 \mathrm{mg}$ of HA with $1.5 \mathrm{~mL}$ of protein dissolved in HEPES buffer (0.01 M HEPES, $0.15 \mathrm{M} \mathrm{NaCl})$ at $\mathrm{pH} 7.4$ or in Tris buffer (0.01 M Tris, $0.15 \mathrm{M} \mathrm{NaCl})$ at $\mathrm{pH} 9.0$, with different concentrations (ranging from 0.1 to $10 \mathrm{mg} / \mathrm{mL}$ ) in a $2 \mathrm{~mL}$ Eppendorf tube. The mixture was maintained in a bascule bath at $37^{\circ} \mathrm{C}$ for 24 hours. For the spectroscopic and thermal investigations, the solid was washed twice with ultrapure water and recovered by centrifuging at 10,000 rpm $(12,700 \mathrm{~g})$ for 3 minutes. The amount of adsorbed protein was determined by calculating the difference between the concentrations of the protein solutions before and after adsorption on HA nanocrystals. 


\section{Bacteria}

The study included the following species: Staphylococcus aureus A170, Listeria monocytogenes, Salmonella enterica serovar Paratyphi, and Escherichia coli. Isolates were obtained from patients hospitalized at the Medical School, University of Naples. All bacteria were characterized using Biolog MicroStation ${ }^{\mathrm{TM}}$ System/MicroLog ${ }^{\mathrm{TM}}$ (User's guide version 5.2.01, Biolog, Hayward, CA, USA) and specimens were confirmed by polymerase chain reaction assay of the genes Hsp 60 (S. aureus), Mono A (L. monocytogenes), invA (S. enterica serovar Paratyphi B), and Stx1 (E. coli). ${ }^{24-27}$ The bacteria were grown as described elsewhere. ${ }^{5}$

\section{Antibacterial activity}

The bacteria were distributed in triplicate into plates $(60 \mu \mathrm{L}$ per well), mixed with a series of dilutions of LF-HA $\left(300-500 \mu \mathrm{g} / \mathrm{mL}, 40 \mu \mathrm{L}\right.$ per well), and incubated at $37^{\circ} \mathrm{C}$ for 20 hours. The minimal concentration of LF-HA causing $100 \%$ growth inhibition $\left(\mathrm{MIC}_{100}\right)$ was determined by measuring absorbance at $600 \mathrm{~nm}$ using a microplate reader (Model 680, Bio-Rad Hercules, CA, USA). ${ }^{6}$

\section{Hemolytic activity}

LF-HA was tested for its hemolytic activity using murine red blood cells. The hemolytic activity was measured according to the formula:

$\mathrm{OD}_{\text {peptide }}-\mathrm{OD}_{\text {negative control }} / \mathrm{OD}_{\text {positive control }}-\mathrm{OD}_{\text {negative control }} \times 100$

where the negative control ( $0 \%$ hemolysis) was represented by erythrocytes suspended in saline while the positive control (100\% hemolysis) was represented by erythrocytes lysed with $1 \%$ Triton $\mathrm{X}-100 .{ }^{6}$ The $\mathrm{LC}_{50}$ value was calculated as described elsewhere. ${ }^{6}$

\section{Cell culture and trials of cytotoxicity}

A human acute monocytic leukemia cell line (THP-1, American Tissue Culture Collection, Rockville, MD, USA) were cultured in complete medium consisting of Roswell Park Memorial Institute medium, $10 \%$ fetal bovine serum, $100 \mathrm{IU} / \mathrm{mL}$ penicillin, and $100 \mu \mathrm{g} / \mathrm{mL}$ streptomycin (all from Gibco, Paisley, Scotland). Cell adhesion was induced with phorbol myristate acetate $(2 \mu \mathrm{g} / \mathrm{mL}$ per well). Cell viability and nitrite production were evaluated as described in another publication ${ }^{6}$ at LF-HA concentrations of $300-500 \mu \mathrm{g} / \mathrm{mL}$ for 24,48 , and 72 hours. A lactate dehydrogenase (LDH) assay was performed using a CytoTox $96^{\circledR}$ Non-Radio cytotoxicity assay kit (Promega, Madison, WI, USA) at 2, 4, and 24 hours.

\section{Antioxidant activity of LF-HA}

The antioxidant activity of LF-HA was assessed as previously described. ${ }^{28}$

\section{Enzyme-linked immunosorbent assay of inflammatory activity}

THP-1 cells $\left(10^{6}\right.$ cells per well $)$ were stimulated with lipopolysaccharide $10 \mu \mathrm{g} / \mathrm{mL}$ for one hour. The THP-1 cells stimulated or not with lipopolysaccharide $10 \mu \mathrm{g} / \mathrm{mL}$ were then treated with LF-HA or acetylsalicylic acid $300 \mu \mathrm{g} / \mathrm{mL}$ for 2, 4, and 24 hours. Tumor necrosis factor (TNF)- $\alpha$, interferon (IFN)- $\gamma$, interleukin (IL)-17, IL-8, IL-12, IL-6, IL-10, and IL-4 levels were assayed by enzyme-linked immunosorbent assay as reported elsewhere. ${ }^{29}$

\section{Chemical analysis}

Calcium and phosphorus content was determined by inductively coupled plasma-optical emission spectrometry (Liberty 200, Varian, Clayton South, Australia). HA and functionalized HA nanocrystals were dissolved in $1 \mathrm{wt} \%$ ultrapure nitric acid. The following analytical wavelengths were chosen: 422 $\mathrm{nm}$ for calcium and $213 \mathrm{~nm}$ for phosphorus.

\section{Electron microscopy}

Transmission electron microscopy investigations were carried out using a 1200 EX microscope fitted with link elemental dispersive X-ray analysis detectors and a 3010 UHR operating at $300 \mathrm{kV}$ (JEOL Ltd, Tokyo, Japan). The powdered samples were ultrasonically dispersed in ultrapure water and a few droplets of the slurry were then deposited on perforated carbon foils supported on conventional copper microgrids. Scanning electron microscopy observations were carried out using an 840A microscope (JEOL Ltd). The specimens were mounted on aluminum stubs using carbon tape and covered with a coating of Au-Pd approximately 10 nm thick using a coating unit (Polaron Sputter Coater E5100, Polaron Equipment, Watford, UK).

\section{X-ray diffraction analysis}

X-ray diffraction powder patterns were collected using Analytical X'Pert Pro equipped with an X'Celerator detector powder diffractometer with $\mathrm{Cu}$ Ka radiation generated at $40 \mathrm{kV}$ and $40 \mathrm{~mA}$.

The degree of HA crystallinity was calculated according to the formula:

$$
\text { Crystallinity }=100 \times \mathrm{C} /(\mathrm{A}+\mathrm{C})
$$


where $\mathrm{C}$ is the area of the peaks in the diffraction pattern ("the crystalline area") and $\mathrm{A}$ is the area between the peaks and the background ("the amorphous area"). ${ }^{30}$

\section{Determination of specific surface area}

Measurements were done using a Sorpty 1750 instrument (Carlo Erba) using $\mathrm{N}_{2}$ absorption at $77 \mathrm{~K}$ and the well known Brunauer, Emmett, and Teller procedure. ${ }^{31}$

\section{X-ray photoelectron spectroscopy analysis}

X-ray photoelectron spectroscopy measurements were performed using an M-Probe (Surface Science Instruments, Mountain View, CA, USA) equipped with a monochromatic Al K $\alpha$ source $(1,486.6 \mathrm{eV})$ with a spot size of $200 \times 750 \mu \mathrm{m}$ and a pass energy of $25 \mathrm{eV}$, providing a resolution of $0.74 \mathrm{eV}$. This equipment has a fixed degree of surface sensitivity due to the collection of photoelectrons at a fixed take-off electron emission angle of $b=0^{\circ}$ (relative to normal sample) between the $\mathrm{X}$-ray axis and the electron analyzer axis $\left(\mathrm{f}=71^{\circ}\right.$ fixed, non variable ). Surface analysis can be performed with a sampling volume that extends from the surface to a maximum depth of 40-50 À. The accuracy of the reported binding energies was estimated to be $\pm 0.2 \mathrm{eV}$. The quantitative data were also checked for accuracy and reproduced several times (at least ten times for each sample) and the percentage error was estimated to be $\pm 1 \%$.

\section{Fourier transform and attenuated total reflectance infrared spectroscopy}

Infrared spectra were recorded on a Nicolet 380 FT-IR spectrometer (Thermo Scientific, Baltimore, MD, USA) equipped with a commercial attenuated total reflectance accessory. The FT-IR spectra were recorded from 4,000 to $400 \mathrm{~cm}^{-1}$ at $2 \mathrm{~cm}^{-1}$ resolution using an IFS 66v/S spectrometer (Bruker Corporation, Karlsruhe, Germany) and $\mathrm{KBr}$ pellets. Spectra were collected by averaging 256 scans at $4 \mathrm{~cm}^{-1}$ resolution.

\section{Analysis of zeta potential}

Electrophoretic determinations were performed using DELSA apparatus (Beckman Coulter Inc., Pasadena, CA, USA). A DELSA 440 instrument was used to determine the electrophoretic velocity of the suspended particles by measuring the Doppler shift of scattered laser light simultaneously at four different scattering angles, ie, $7.5^{\circ}, 15.0^{\circ}, 22.5^{\circ}$, and $30.0^{\circ}$. Suspensions of HA were prepared as follows: $0.05 \mathrm{~g} / \mathrm{L}$ of $\mathrm{HA}$ in $10^{-2} \mathrm{M} \mathrm{KNO}_{3}$ (constant ionic strength) at a spontaneous constant $\mathrm{pH}$.

\section{Results Synthetic biomimetic HA nanocrystals}

In this study, we analyzed the antimicrobial, anti-inflammatory, and antioxidant activity of LF delivered by synthetic biomimetic HA nanocrystals. Biomimetic HA nanocrystals were synthesized as previously reported, ${ }^{23}$ with a carbonate content of $5 \% \pm 2 \%$, resembling that of bone HA where the carbonate content ranges from $4 \mathrm{wt} \%$ to $8 \mathrm{wt} \%$.

The FTIR spectrum for the synthesized biomimetic HA (Figure 1A) not only reveals the characteristic adsorption bands of phosphates at $1,034 \mathrm{~cm}^{-1}$ and $1,100 \mathrm{~cm}^{-1}$, but also the adsorption bands due to the presence of carbonate. A small adsorption band at $880 \mathrm{~cm}^{-1}$ was utilized to evaluate the percent carbonate content in HA, and adsorption bands at $1,466 \mathrm{~cm}^{-1}, 1,422 \mathrm{~cm}^{-1}$, and $1,545 \mathrm{~cm}^{-1}$ and was consistent with carbonate type A (hydroxyl site)-substituted and type B (phosphate site)-substituted HA nanocrystals, the latter closely resembling the prevalent type B carbonate substitution in the HA found in human bone (Figure 1B). ${ }^{32}$

In Figure 2A, a transmission electron microscopy image of the synthesized HA nanocrystals reveals their planar acicular morphology, which closely resembles that of HA nanocrystals in bone (Figure 2C). The crystals have a plate-like morphology (length and width about $110 \pm 5 \mathrm{~nm}$ and $20 \pm 3 \mathrm{~nm}$, respectively, and a thickness of about $8 \pm 2 \mathrm{~nm}$ ). The main crystal dimension is elongated towards the crystallographic $\mathrm{c}$-axis, as derived by the orientation of fringes $0.34 \mathrm{~nm}$ apart and related to the (002) planes (Figure 2B). It is important to observe how the fringes related to the (002) crystallographic planes are homogeneously extended in the whole crystal core up to near the surface neighboring the crystal. The surface surrounding the nanocrystal appears to be amorphous without a defined crystallographic order. This finding is confirmed by a nearly stoichiometric calcium/phosphorus molar ratio of 1:7 as determined by chemical analysis in bulk and a surface calcium/phosphorus molar ratio of 1:3 when determined by $\mathrm{X}$-ray photoelectron spectroscopy analysis. The presence of 5\% phosphate anions substituted by carbonate anions produces a pseudoamorphous layer without crystalline order on the surface of the nanocrystals. The amorphous surface is responsible for the zeta potential of $-20.5 \pm 1.5 \mathrm{mV}$ shown by the HA nanocrystals at physiological $\mathrm{pH}$ (7.4). The high reactivity of the HA nanocrystals is ascribed to these findings, together with the high specific surface area of about $110 \mathrm{~m}^{2} / \mathrm{g}$, which is only slightly lower than the value of $120 \mathrm{~m}^{2} / \mathrm{g}$ obtained for biological nanocrystals.

The powder X-ray diffraction pattern for the synthesized HA nanocrystals reported in Figure 3A shows the 
A

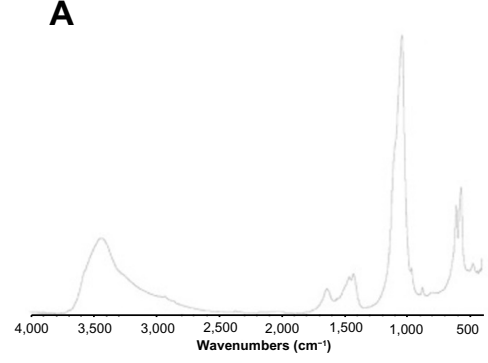

B

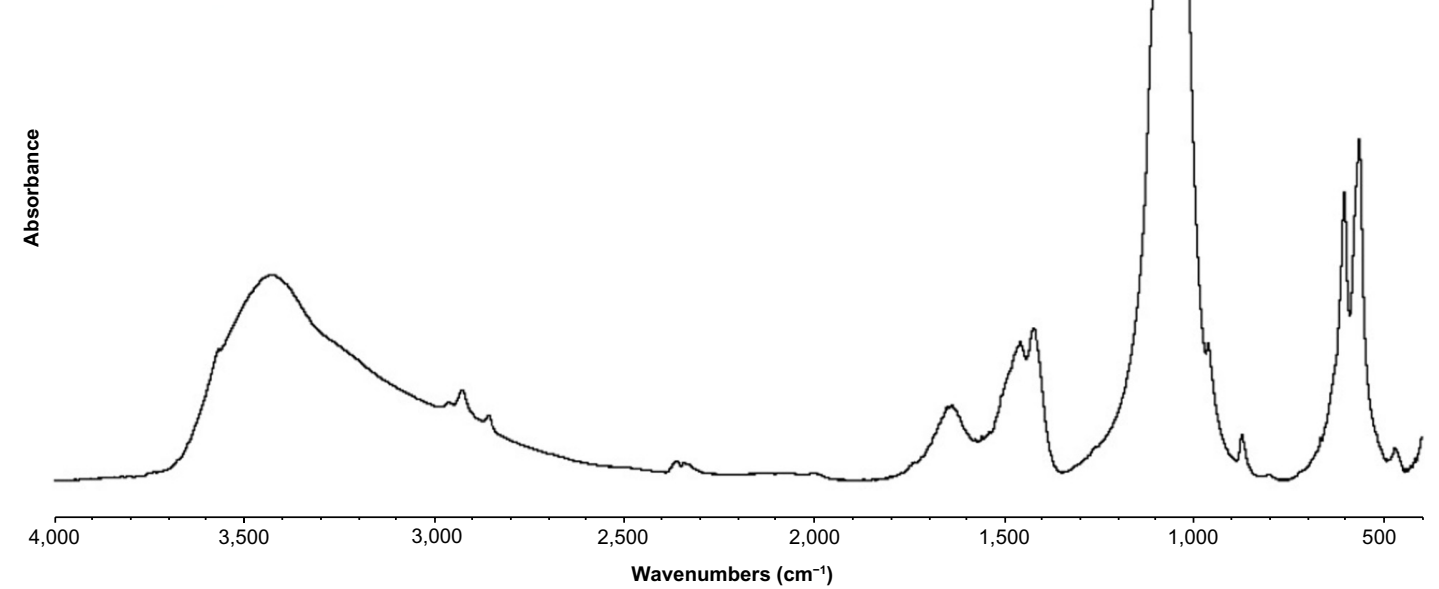

Figure I Fourier transform infrared spectrum of the synthesized biomimetic HA nanocrystals revealing absorption bands due to phosphate groups at I,034 $\mathrm{cm}^{-1}$ and I, I $00 \mathrm{~cm}^{-1}$ and absorption bands due to carbonate groups, ie, a small band at $880 \mathrm{~cm}^{-1}$ and others at I,466 cm-1, I,422 $\mathrm{cm}^{-1}$, and I,545 cm-1, which are consistent with type A and type B, respectively, carbonate-substituted hydroxyapatite $(\mathbf{B})$ and closely resemble natural hydroxyapatite in human bone $(\mathbf{A})$.

characteristic diffraction maxima for HA single phase (JCPDS 9-32). The diffraction pattern of the synthesized HA shows poorly defined diffraction maxima, indicating a relatively low degree of crystallinity. In Figure 3B, the X-ray diffraction pattern of deproteinated bone HA is reported for

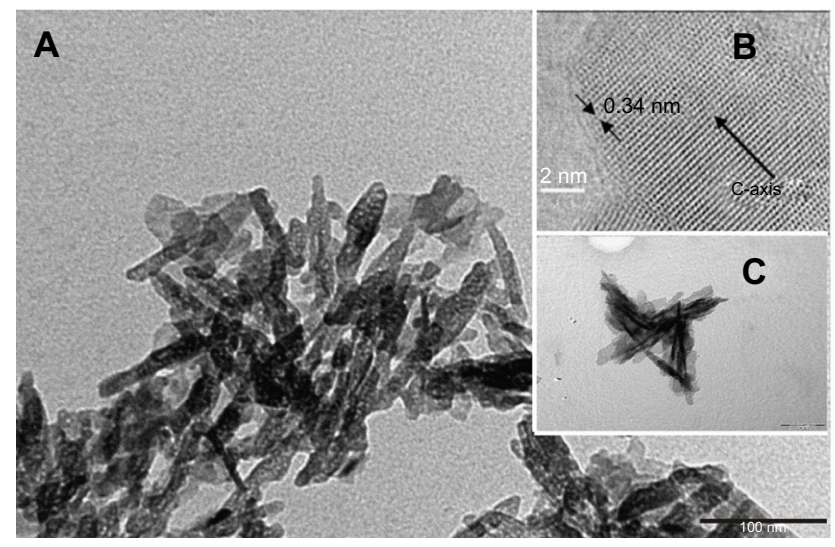

Figure 2 (A) Transmission electron microscopy (TEM) image of a synthetic hydroxyapatite nanocrystal with a planar acicular morphology mimicking the bone biogenic hydroxyapatite nanocrystals. (B) High-resolution image of a single carbonate hydroxyapatite nanocrystal with the c crystallographic axis parallel to the main crystal dimension and orthogonal to the fringes related to the (002) crystallographic planes. The arrows show the order present in the hydroxyapatite crystal. High resolution TEM image shows how it is possible to observe the regular packing present into the crystal. (C) TEM image of bone hydroxyapatite nanocrystals. comparison. The degree of synthetic HA crystallinity ${ }^{30}$ was calculated according to the method described by Sherman, ${ }^{30}$ obtaining a value of $45 \%$, which is increased in respect to the value of $28 \%$ determined from the X-ray diffraction pattern of natural apatite in deproteinated bone.

\section{Preparation and characterization of LF-coated HA}

Synthetic biomimetic HA nanocrystals were surfacefunctionalized at $\mathrm{pH} 7.4$ by different amounts of lactoferrin molecules using the method reported by Iafisco et al. ${ }^{20}$ Isotherm LF adsorption onto biomimetic HA nanocrystals at $\mathrm{pH} 7.4$ is reported in Figure 4, where the adsorbed amount (C Lactoferrin, in $\mathrm{mg} / \mathrm{m}^{2}$ ) is plotted against the protein concentration after adsorption (C Lactoferrin in $\mathrm{mg} / \mathrm{mL}$ ). The plot is characterized by an initial slope, indicating high protein affinity for the HA surface.

The increase in LF concentration in the buffer solution enhances the surface coverage until it is complete. The absorption-saturation yields a plateau value corresponding to the maximum amount of LF surface immobilization of about $0.8 \mathrm{mg} / \mathrm{m}^{2}$. The isoelectric point of LF is 8.5 , and it thus has a net positive charge below the isoelectric point. ${ }^{33}$ At $\mathrm{pH}$ 7.4, the positive electrostatic surface potential of 

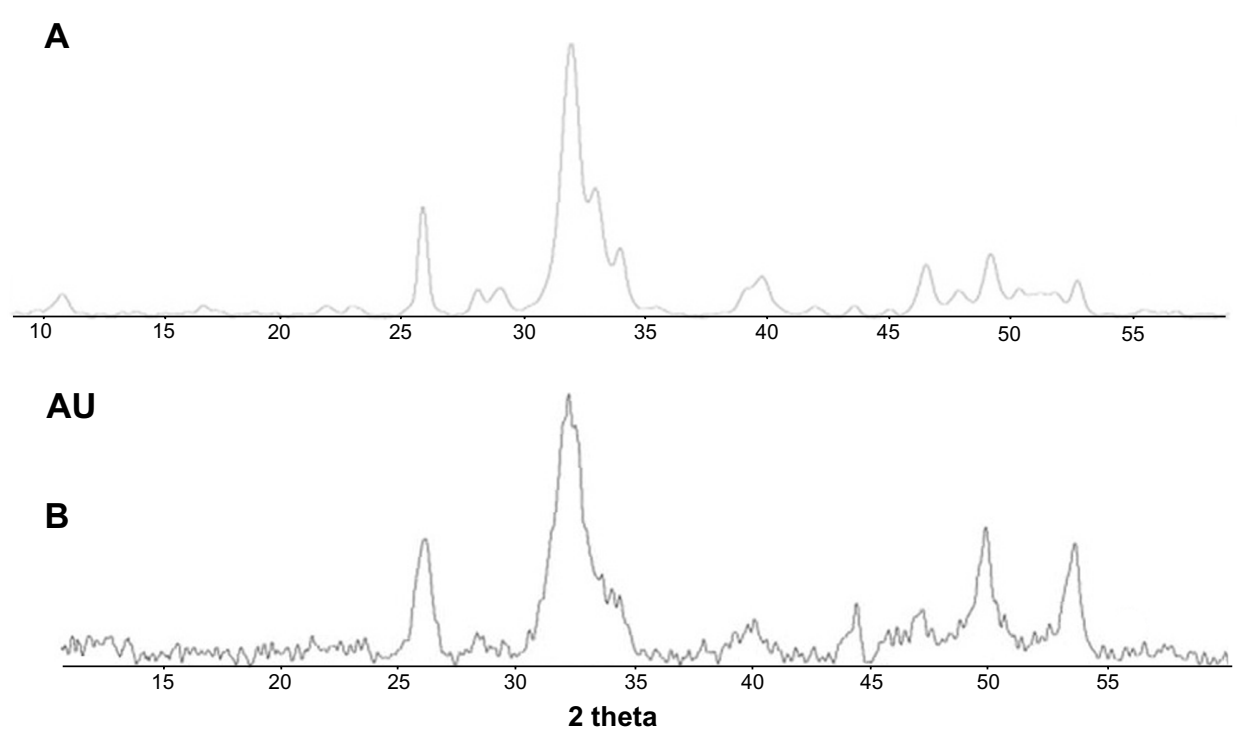

Figure 3 (A) Powder X-ray diffraction pattern of synthesized hydroxyapatite nanocrystals and (B) deproteinated bone hydroxyapatite. Abbreviation: $\mathrm{AU}$, arbitrary unit.

LF produces a strong surface interaction, with the negative HA nanocrystals having a zeta potential of $-20.5 \pm 1.5 \mathrm{mV}$ and avoiding protein-protein interaction. This electrostatic interaction leads to formation of an LF monolayer coated onto the HA nanocrystals. The HA morphology and the nanodimension do not appreciably affect the conformation of the absorbed LF. At pH 7.4, the LF covering the HA nanocrystals appeared to be only slightly unfolded, with a small fraction of the alpha-helix structure being converted into turn while the beta-sheet content remained almost unchanged. ${ }^{20}$ Nanohybrid composite made of biomimetic HA nanocrystals surface - covered of $0.8 \mathrm{mg} / \mathrm{m}^{2}$ (LF-HA) were prepared in order to test their biological activity.

\section{Antimicrobial and hemolytic activities}

Synthetic biomimetic HA nanocrystals surface-functionalized with LF were tested for their antibacterial activity against
S. aureus A170, L. monocytogenes, S. enterica serovar Paratyphi B, and E. coli. LF molecules delivered by the biomimetic HA nanocrystals were active against both Gram positive and Gram negative bacteria. LF molecules effectiveness depend on LF-HA concentration. The antimicrobial activity of LF-HA and LF is shown at different concentrations $(300-500 \mu \mathrm{g} / \mathrm{mL})$ in Table $1 \mathrm{~A}$ and B. The antimicrobial activity of LF-HA at a concentration of $300 \mu \mathrm{g} / \mathrm{mL}$ is higher than that of unconiugated LF. The LF-HA nanohybrid composite at a concentration of $300 \mu \mathrm{g} / \mathrm{mL}$ had low hemolytic activity $(10 \%)$ and the $\mathrm{LC}_{50}$ value was $526.7 \mu \mathrm{g} / \mathrm{mL}$.

\section{Cytotoxic activity and antioxidant capacity}

LF-HA was slightly cytotoxic when tested in a THP-1 cell line at concentrations of $300-500 \mu \mathrm{g} / \mathrm{mL}$. The THP- 1 cells remained viable for up to 72 hours (Table 2). In addition,

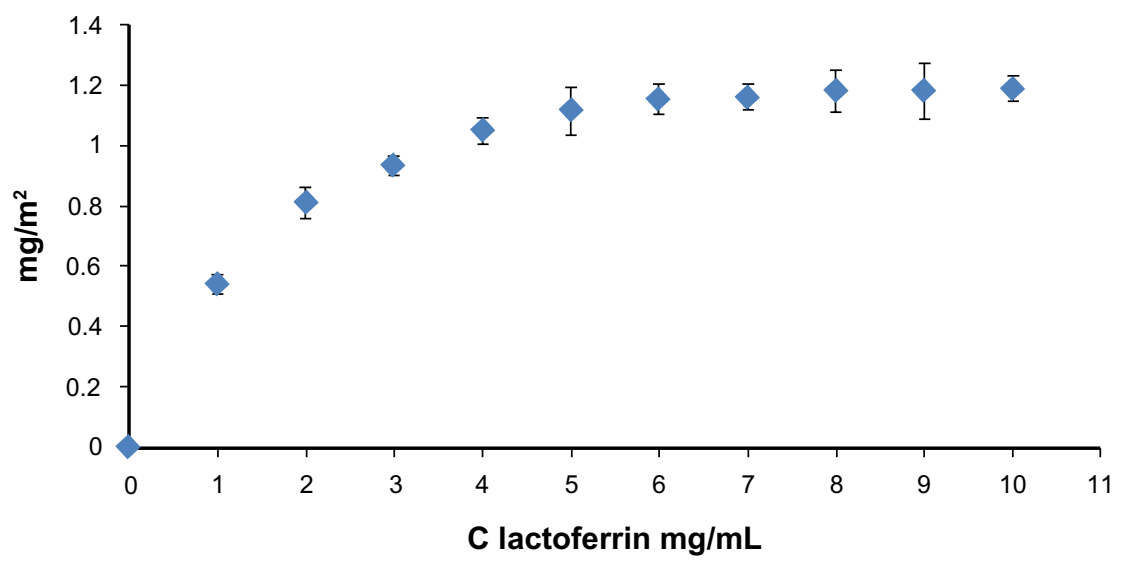

Figure 4 Adsorption isotherm of lactoferrin on biomimetic hydroxyapatite nanocrystals at $\mathrm{pH}$ 7.4. The adsorbed lactoferrin is plotted against the protein concentration after adsorption. 
Table I Antimicrobial activity of LF-HA versus unconiugated LF

\begin{tabular}{|c|c|c|c|c|c|}
\hline Strains & $\begin{array}{l}\text { LF-HA } \\
300 \mu \mathrm{g} / \mathrm{mL}\end{array}$ & $\begin{array}{l}\text { LF-HA } \\
350 \mu \mathrm{g} / \mathrm{mL}\end{array}$ & $\begin{array}{l}\text { LF-HA } \\
400 \mu \mathrm{g} / \mathrm{mL}\end{array}$ & $\begin{array}{l}\text { LF-HA } \\
450 \mu \mathrm{g} / \mathrm{mL}\end{array}$ & $\begin{array}{l}\text { LF-HA } \\
500 \mu \mathrm{g} / \mathrm{mL}\end{array}$ \\
\hline \multicolumn{6}{|l|}{ (A) } \\
\hline Staphylococcus aureus & $61 \%$ & $65 \%$ & $70 \%$ & $77 \%$ & $80 \%$ \\
\hline Salmonella Paratyphi B & $63 \%$ & $66 \%$ & $71 \%$ & $78 \%$ & $81 \%$ \\
\hline Escherechia coli & $65 \%$ & $68 \%$ & $72 \%$ & $75 \%$ & $78 \%$ \\
\hline \multirow[t]{3}{*}{ Listeria monocytogenes } & $60 \%$ & $63 \%$ & $70 \%$ & $75 \%$ & $80 \%$ \\
\hline & LF & LF & LF & LF & LF \\
\hline & $300 \mu \mathrm{g} / \mathrm{mL}$ & $350 \mu \mathrm{g} / \mathrm{mL}$ & $400 \mu \mathrm{g} / \mathrm{mL}$ & $450 \mu \mathrm{g} / \mathrm{mL}$ & $500 \mu \mathrm{g} / \mathrm{mL}$ \\
\hline \multicolumn{6}{|l|}{ (B) } \\
\hline Staphylococcus aureus & $28 \%$ & $30 \%$ & $36 \%$ & $40 \%$ & $42 \%$ \\
\hline Salmonella Paratyphi B & $23 \%$ & $28 \%$ & $31 \%$ & $35 \%$ & $41 \%$ \\
\hline Escherechia coli & $25 \%$ & $31 \%$ & $36 \%$ & $42 \%$ & $48 \%$ \\
\hline Listeria monocytogenes & $22 \%$ & $26 \%$ & $30 \%$ & $37 \%$ & $40 \%$ \\
\hline
\end{tabular}

Note: (A) Antimicrobial activity at different concentrations $(300-500 \mu \mathrm{g} / \mathrm{mL}$ ) of LF-HA against Gram-positive (Staphylococcus aureus and Listeria monocytogenes) and Gramnegative (Escherichia coli and Salmonella Paratyphi B) bacteria ( $10^{6}$ colony forming units per well; $\left.60 \mu \mathrm{L}\right)$. (B) Antimicrobial activity at different concentrations ( $\left.300-500 \mu g / \mathrm{mL}\right)$ of LF against Gram-positive (S. aureus and L. monocytogenes) and Gram-negative (E. coli and Salmonella Paratyphi B) bacteria (I $0^{6}$ colony forming units per well; $60 \mu \mathrm{L}$ ).

Abbreviations: HA, hydroxyapatite; LF, lactoferrin.

LF-HA induced low production of $\mathrm{NO}_{2}$ in THP-1 cells. Production of $\mathrm{NO}_{2}$ was reduced in cells stimulated with lipopolysaccharide and then treated with LF-HA compared with control cells (stimulated only with lipopolysaccharide, Table 3). The LDH enzyme released by THP-1 cells was used as the endpoint for the study of cellular toxicity (Figure 1A).

LF-HA induced low production of LDH in THP-1 cells. Release of LDH into the medium is a sign of necrotic cell death, ${ }^{34}$ and production of LDH was reduced in cells stimulated with lipopolysaccharide $10 \mu \mathrm{g} / \mathrm{mL}$ and then treated with LF-HA compared with the positive control provided by the kit (Figure 5A). The antioxidant properties of HA and LF alone or combined in the hybrid LF-HA composites was evaluated using the ABTS test (HA, 14,632 mmol/L; LF, 2,605 mmol/L; LF-HA, 15,294 mmol/L). A small increase in antioxidant activity was found in the LF-HA composite.

\section{Immunomodulatory activity}

We also investigated the immunomodulatory activity of LF-HA in THP-1 cells stimulated by lipopolysaccharide. For this purpose, the performance of selected cytokines, including TNF- $\alpha$, IFN- $\gamma$, IL-17, IL-4, IL-12, IL-8, IL-6, and IL-10, was evaluated by enzyme-linked immunosorbent assay.
Cytokines can be considered as an important parameter for defining inflammation. ${ }^{35}$ Treatment of THP-1 cells with acetylsalicylic acid or LF-HA did not induce any inflammatory response, and levels of TNF- $\alpha$, IFN- $\gamma$, IL-17, IL-4, IL-6, IL-10, IL-12, and IL-8 appeared to be low. After stimulation of THP-1 cells by lipopolysaccharide, an increase in levels of proinflammatory cytokines, ie, TNF- $\alpha$, IFN- $\gamma$, IL- 6 , and IL-17, was observed, with a peak after 4 hours (Figure 5B). After treatment of lipopolysaccharide-stimulated THP-1 cells with LF-HA, the levels of proinflammatory cytokines decreased, while the levels of others, such as IL-4, IL-10, IL-12, and IL-8, showed an increase, reaching a peak at 4 hours. On treating lipopolysaccharide-stimulated THP-1 cells with acetylsalicylic acid, there was a decrease in TNF- $\alpha$, IFN- $\gamma$, IL- 6 , and IL-17 levels and an increase in IL-4, IL-10, IL-12, and IL-8 levels (Figure 5B). THP-1 cells were treated with lipopolysaccharide, the supernatant was collected at 2, 4, 6, 8, 12, and 24 hours, and TNF- $\alpha$ and IL-6 levels were quantified. These cytokines show a high level of expression for up to 8 hours (data not shown). In THP-1 cells stimulated with lipopolysaccharide and treated with LF-HA, TNF- $\alpha$, and IL- 6 levels started to decrease 4 hours after treatment.

Table 2 Analysis of cell viability

\begin{tabular}{|c|c|c|c|c|c|c|}
\hline Time (h) & THP-I & $\begin{array}{l}\text { THP-I + LF-HA } \\
300 \mu \mathrm{g} / \mathrm{mL}\end{array}$ & $\begin{array}{l}\text { THP-I + LF-HA } \\
350 \mu \mathrm{g} / \mathrm{mL}\end{array}$ & $\begin{array}{l}\text { THP-I + LF-HA } \\
400 \mu \mathrm{g} / \mathrm{mL}\end{array}$ & $\begin{array}{l}\text { THP-I + LF-HA } \\
450 \mu \mathrm{g} / \mathrm{mL}\end{array}$ & $\begin{array}{l}\text { THP-I + LF-HA } \\
500 \mu \mathrm{g} / \mathrm{mL}\end{array}$ \\
\hline $24 \mathrm{~h}$ & $99 \%$ & $83 \%$ & $76 \%$ & $71 \%$ & $70 \%$ & $67 \%$ \\
\hline $48 \mathrm{~h}$ & $96 \%$ & $80 \%$ & $74 \%$ & $70 \%$ & $67 \%$ & $64 \%$ \\
\hline $72 \mathrm{~h}$ & $90 \%$ & $77 \%$ & $72 \%$ & $68 \%$ & $65 \%$ & $62 \%$ \\
\hline
\end{tabular}

Note: THP-I cells were treated with LF-HA $(300-500 \mu \mathrm{g} / \mathrm{mL})$ and cell viability was determined at 24,48 , or 72 hours by the Trypan blue test. Abbreviations: HA, hydroxyapatite; LF, lactoferrin; h, hours. 
Table 3 Time couse of $\mathrm{NO}_{2}$ production by THP-I cells/macrophages.

\begin{tabular}{|c|c|c|c|}
\hline & \multicolumn{3}{|l|}{ Time (h) } \\
\hline & $24 \mathrm{~h}$ & $48 \mathrm{~h}$ & $72 \mathrm{~h}$ \\
\hline THP-I & $0,596 \pm 0.02 \mu \mathrm{mol}$ & $0,76 \pm 0.08 \mu \mathrm{mol}$ & $0,996 \pm 0.04 \mu \mathrm{mol}$ \\
\hline THP-I + LPS & $3,910 \pm 0.01 \mu \mathrm{mol}$ & $4,415 \pm 0.2 \mu \mathrm{mol}$ & $5,312 \pm 0.03 \mu \mathrm{mol}$ \\
\hline LF-HA $300 \mu \mathrm{g} / \mathrm{mL}$ & $\mathrm{I}, 120 \pm 0.04 \mu \mathrm{mol}$ & $\mathrm{I}, 520 \pm 0.25 \mu \mathrm{mol}$ & $\mathrm{I}, 720 \pm 0.04 \mu \mathrm{mol}$ \\
\hline LF-HA $350 \mu \mathrm{g} / \mathrm{mL}$ & $\mathrm{I}, 140 \pm 0.03 \mu \mathrm{mol}$ & $\mathrm{I}, 449 \pm 0.12 \mu \mathrm{mol}$ & $\mathrm{I}, 740 \pm 0.046 \mu \mathrm{mol}$ \\
\hline LF-HA $400 \mu \mathrm{g} / \mathrm{mL}$ & $\mathrm{I}, 175 \pm 0 . \mathrm{I} \mu \mathrm{mol}$ & $\mathrm{I}, 775 \pm 0.16 \mu \mathrm{mol}$ & $\mathrm{I}, 875 \pm 0.038 \mu \mathrm{mol}$ \\
\hline LF-HA $450 \mu \mathrm{g} / \mathrm{mL}$ & $\mathrm{I}, 25 \pm 0.04 \mu \mathrm{mol}$ & $\mathrm{I}, 655 \pm 0.07 \mu \mathrm{mol}$ & $\mathrm{I}, 958 \pm 0.04 \mu \mathrm{mol}$ \\
\hline LF-HA $500 \mu \mathrm{g} / \mathrm{mL}$ & $\mathrm{I}, 278 \pm 0.04 \mu \mathrm{mol}$ & $\mathrm{I}, 878 \pm 0.09 \mu \mathrm{mol}$ & $\mathrm{I}, 968 \pm 0.16 \mu \mathrm{mol}$ \\
\hline LPS + LF-HA $300 \mu \mathrm{g} / \mathrm{mL}$ & $\mathrm{I}, 814 \pm 0.12 \mu \mathrm{mol}$ & $\mathrm{I}, 940 \pm 0.0 \mathrm{I} \mu \mathrm{mol}$ & $\mathrm{I}, 99 \mathrm{I} \pm 0.25 \mu \mathrm{mol}$ \\
\hline LPS + LF-HA $350 \mu \mathrm{g} / \mathrm{mL}$ & $\mathrm{I}, 775 \pm 0.04 \mu \mathrm{mol}$ & 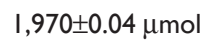 & $2,075 \pm 0.10 \mu \mathrm{mol}$ \\
\hline LPS + LF-HA $400 \mu \mathrm{g} / \mathrm{mL}$ & $\mathrm{I}, 950 \pm 0.013 \mu \mathrm{mol}$ & $\mathrm{I}, 980 \pm 0.03 \mu \mathrm{mol}$ & $2,19 \pm 0.02 \mu \mathrm{mol}$ \\
\hline LPS + LF-HA $450 \mu \mathrm{g} / \mathrm{mL}$ & $2,159 \pm 0.11 \mu \mathrm{mol}$ & $2,359 \pm 0.07 \mu \mathrm{mol}$ & $2,43 \mathrm{I} \pm 0.2 \mu \mathrm{mol}$ \\
\hline LPS + LF-HA $500 \mu \mathrm{g} / \mathrm{mL}$ & $2,250 \pm 0.17 \mu \mathrm{mol}$ & $2,395 \pm 0.14 \mu \mathrm{mol}$ & $2,249 \pm 0.18 \mu \mathrm{mol}$ \\
\hline
\end{tabular}

Note: $\mathrm{NO}_{2}$ production by untreated THP-I cells, THP-I cells stimulated with LPS $(10 \mu \mathrm{g} / \mathrm{mL})$, THP-I cells treated with LF-HA (300-500 $\left.\mu \mathrm{g} / \mathrm{mL}\right)$ and THP-I cells stimulated with LPS $(10 \mu \mathrm{g} / \mathrm{mL})$ and treated with LF-HA (300-500 $\mu \mathrm{g} / \mathrm{mL})$. The data are expressed as $\mu \mathrm{mol}$ of $\mathrm{NO}_{2}$ for $10^{6}$ input cells, and shown as the mean \pm standard deviation of three different experiments, each performed in triplicate.

Abbreviations: HA, hydroxyapatite; LF, lactoferrin; LPS, lipopolysaccharide; h, hours.
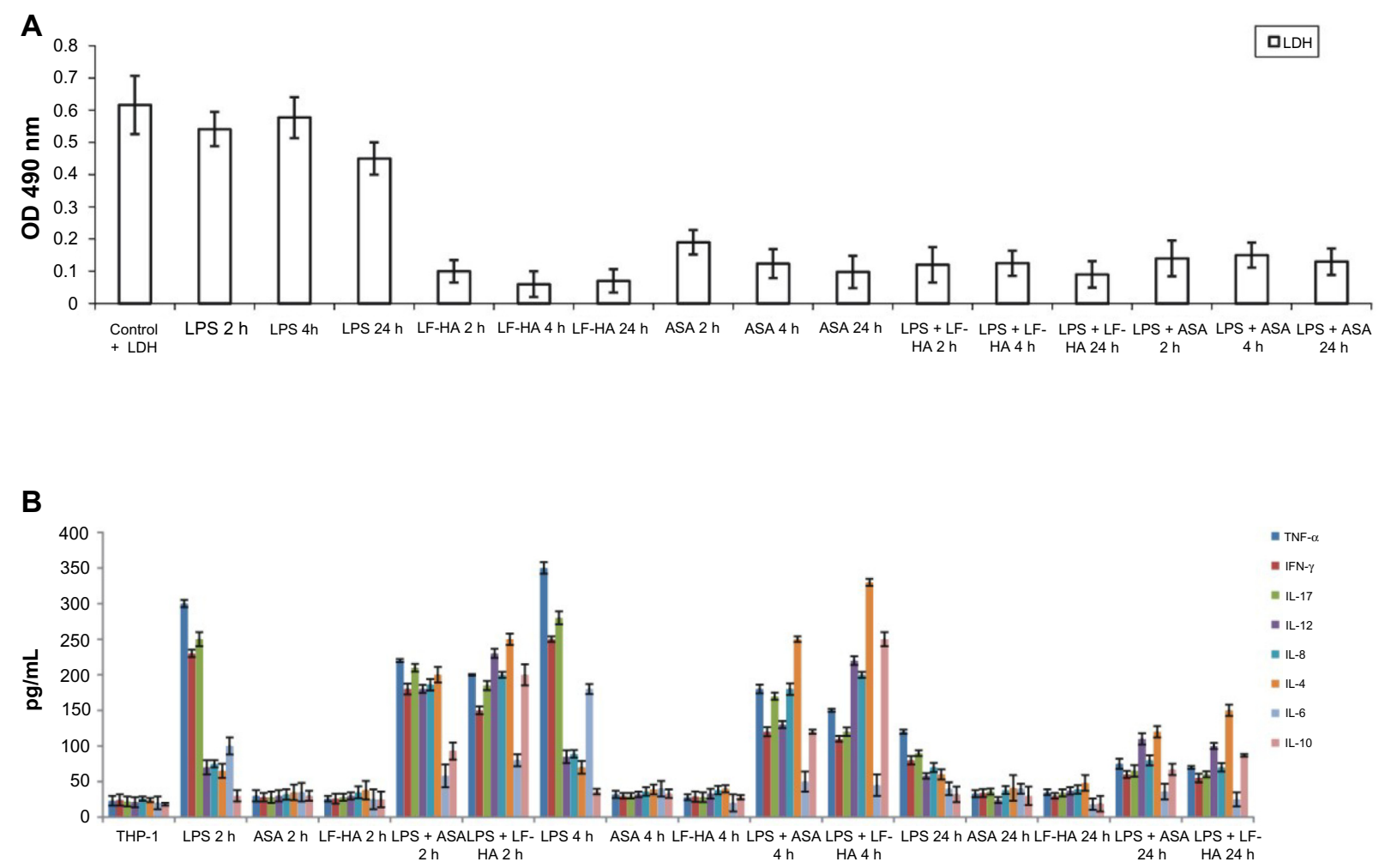

Figure 5 (A) LDH assay. The effect of LF-HA on LDH release in untreated THP-I cells, THP-I cells stimulated with LPS $10 \mu g / \mathrm{mL}$ for 2,4 , or 24 hours, THP-I cells treated with LF-HA $300 \mu \mathrm{g} / \mathrm{mL}$ or ASA $300 \mu \mathrm{g} / \mathrm{mL}$ for 2 , 4 , or 24 hours, and THP-I cells stimulated with LPS $10 \mu \mathrm{g} / \mathrm{mL}$ and then treated with LF-HA $300 \mu \mathrm{g} / \mathrm{mL}$ or ASA $300 \mu \mathrm{g} / \mathrm{mL}$ for 2, 4, or 24 hours. Positive control: control plus LDH provided by the kit. (B) Anti-inflammatory activity. IFN- $\gamma$, TNF- $\alpha$, IL-I7, IL-4, IL-I2, IL-8, IL-6, and IL-I0 levels were determined by a sandwich enzyme-linked immunosorbent assay test in untreated THP-I cells, THP-I cells stimulated with LPS I0 $\mu \mathrm{g} / \mathrm{mL}$ for 2 , 4 , or 24 hours, THP-I cells treated with LF-HA $300 \mu \mathrm{g} / \mathrm{mL}$ or ASA $300 \mu \mathrm{g} / \mathrm{mL}$ for 2, 4, or 24 hours, and THP-I cells stimulated with LPS $10 \mu \mathrm{g} / \mathrm{mL}$ and then treated with LF-HA $300 \mu \mathrm{g} / \mathrm{mL}$ or ASA $300 \mu \mathrm{g} / \mathrm{mL}$ for 2, 4, or 24 hours. Negative control: THP-I cells in Roswell Park Memorial Institute medium. Results from the representative experiments are presented as the mean \pm standard deviation.

Abbreviations: ASA, acetylsalicylic acid; HA, hydroxyapatite; LDH, lactate dehydrogenase; IFN- $\gamma$, interferon gamma; IL, interleukin; LF, lactoferrin; LPS, lipopolysaccharide; TNF- $\alpha$, tumor necrosis factor alpha; h, hours. 
In the presence of lipopolysaccharide, LF-HA specifically inhibits the release of proinflammatory cytokines and increases the secretion of anti-inflammatory cytokines, both in vivo and in vitro. LF-HA downregulates the synthesis of proinflammatory cytokines due to its ability to bind lipopolysaccharide through the LF domain. Therefore, LF-HA competes with lipopolysaccharide-binding protein for binding to lipopolysaccharide and blocks transport of endotoxins to mCD14, which is expressed on the surface of macrophages. By binding lipopolysaccharide, LF-HA prevents activation of NF-kB and consequently the production of proinflammatory cytokines. ${ }^{36}$

Based on the results obtained here, we can conclude that the performance of TNF- $\alpha$ and IL- 6 in THP-1 cells stimulated with lipopolysaccharide and then treated with acetylsalicylic acid is comparable with that in cells stimulated with lipopolysaccharide and then treated with LF-HA. Further tests have shown that LF-HA downregulates the level of proinflammatory cytokines and that it also demonstrates immunomodulatory activity. These effects appeared to be comparable with those of acetylsalicylic acid, a well known anti-inflammatory drug (Figure 5B) that helps to regulate the immune response.

\section{Conclusion}

Careless prescribing has led to the ineffectiveness of some antibiotics that were once considered adequate. ${ }^{35}$ In this situation, antimicrobial proteins, in their natural form alone or combined with other molecules, could represent a solution to this problem. Antimicrobial molecules are characterized by a broad spectrum of activity against Gram-positive and Gram-negative bacteria and have a low level of toxicity in eukaryotic cells. ${ }^{6}$ In this work, we investigated the antimicrobial, anti-inflammatory, and antioxidant activity of an LF-HA nanohybrid composite composed of biomimetic HA nanocrystals surface-covered of $0.8 \mathrm{mg} / \mathrm{m}$.

In conclusion, it can be stated that the known antibacterial, immunomodulatory, and antioxidant properties of LF are increased when molecules of this protein are surface-linked to biomimetic HA nanocrystals..$^{36,37,38}$ The present findings show that the LF-HA hybrid composite has potential with regard to preparation of antimicrobial and antioxidant material useful for the design of innovative technological biomedical applications.

\section{Acknowledgments}

The authors wish to thank Dr Giulia Graziani, Dr Salvatore Esposito, Filomena Di Ruocco, and Claudio Tracanna for their assistance for this research. In addition, they thank the RBAP114AMK, RINAME Project (funds for selected research topics) and the Interuniversity Consortium for Research on Chemistry of Metals in Biological Systems and Chemical Center Srl for financial support.

\section{Disclosure}

The authors report no conflicts of interest and that they received no payment for preparation of this paper.

\section{References}

1. Livermore DM. The need for new antibiotics. Clin Microbiol Infec. 2004;4:1-9.

2. Capparelli R, Amoroso MG, Palumbo D, Iannaccone M, Faleri C, Cresti M. Two plant puroindolines colocalize in wheat seed and in vitro synergistically fight against pathogens. Plant Mol Biol. 2005;58:857-867.

3. Palumbo D, Iannaccone M, Porta A, Capparelli R. Experimental antibacterial therapy with puroindolines, lactoferrin and lysozyme in Listeria monocytogenes-infected mice. Microbes Infect. 2010;12:538-545.

4. Capparelli R, Ventimiglia I, Palumbo D, et al. Expression of recombinant puroindolines for the treatment of staphylococcal skin infections (Acne vulgaris). J Biotechnol. 2007;128:606-614.

5. Capparelli R, Romanelli A, Iannaccone M, et al. Synergistic antibacterial and anti-inflammatory activity of temporin A and modified temporin B in vivo. PLoS One. 2009;4:e7191.

6. Capparelli R, De Chiara F, Nocerino N, et al. New perspectives for natural antimicrobial peptides: application as antinflammatory drugs in a murine model. BMC Immunol. 2012;13:61.

7. González-Chávez SA, Arévalo-Gallegos S, Rascón-Cruz Q. Lactoferrin: structure, function and applications. Int J Antimicrob Agents. 2009;33: 301. e1-301.e8.

8. Valenti P, Antonini G. Lactoferrin: an important host defence against microbial and viral attack. Cell Mol Life Sci. 2005;62:2576-2587.

9. Metz-Boutique MH, Jolles J, Mazurier J, et al. Human lactotransferrin: amino acid sequence and structural comparisons with other transferrins. Eur J Biochem. 1984;145:659-676.

10. Steijns JM, Van Hooijdonk AC. Occurrence structure biochemical properties and technological characteristics of lactoferrin. Br J Nutr. 2000;84:7-11.

11. Conesa C, Sánchez L, Rota C, et al. Isolation of lactoferrin from milk of different species: calorimetric and antimicrobial studies. Comp Biochem Physiol Part B. 2008;150:131-139.

12. Legrand D, Mazurier J. A critical review of the roles of host lactoferrin in immunity. Biometals. 2010;23:365-376.

13. Sánchez L, Peiró JM, Oria R, Castillo H, Brock JH, Calvo M. Kinetic parameters for denaturation of bovine milk lactoferrin. J Food Sci. 1992;57:873-879.

14. Iafisco M, Foltran I, Di Foggia M, Bonora S, Roveri N. Calorimetric and Raman investigation of cow's milk lactoferrin. J Therm Anal Calorim. 2011;103:41-47.

15. Latour RA. In the biomaterials field, its study is fundamental: to learn more about the biomineralization process in vivo, but also to test the material performance in the biological environment. Biointerphases. 2008;3:FC2-FC12.

16. Dee KC, Puleo DA, Bizios R. An Introduction to Tissue Biomaterial Interactions. Hoboken, NJ, USA: Wiley-Liss; 2003.

17. Roveri N, Palazzo B, Iafisco M. The role of biomimetism in developing nanostructured inorganic matrices for drug delivery. Expert Opin Drug Deliv. 2008;5:861-877.

18. Kandori K, Fudo A, Ishikawa T. Adsorption of myoglobin onto various synthetic hydroxyapatite particles. Phys Chem Chem Phys. 2000;2: 2015-2020. 
19. Akazawa T, Kobayashi M, Yoshida M, et al. Improved liquid chromatographic separation of different proteins by designing functional surfaces of cattle bone-originated apatite. J Chromatogr A. 1999;862: 217-220.

20. Iafisco M, Di Foggia M, Bonora S, Prat M, Roveri N. Adsorption and spectroscopic characterization of lactoferrin on hydroxyapatite nanocrystals. Dalton Trans. 2011;40:820-827.

21. Iafisco M, Palazzo B, Marchetti M, et al. Smart delivery of antitumoral platinum complexes from biomimetic hydroxyapatite nanocrystals. J Mater Chem. 2009;19:8385-8392.

22. Iafisco M, Palazzo B, Martra G, et al. Nanocrystalline carbonate-apatites: role of $\mathrm{Ca} / \mathrm{P}$ ratio on the upload and release of anticancer platinum bisphosphonates. Nanoscale. 2012;4:206-217.

23. Palazzo B, Walsh D, Iafisco M, et al. Amino acid synergetic effect on structure, morphology and surface properties of biomimetic apatite nanocrystals. Acta Biomater. 2009;5:1241-1252.

24. Blaiotta G, Ercolini D, Pennacchia C, et al. PCR detection of staphylococcal enterotoxin genes in Staphylococcus spp. strains isolated from meat and dairy products. Evidence for new variants of seG and seI in S. aureus AB-8802. J Appl Microbiol. 2004;97:719-730.

25. Bubert A, Hein I, Rauch M, et al. Detection and differentiation of Listeria spp. by a single reaction based on multiplex PCR. Appl Environ Microbiol. 1999;65:4688-4692.

26. Chiu CH, Ou JT. Rapid identification of Salmonella serovars in feces by specific detection of virulence genes, invA and spvC, by an enrichment broth culture-multiplex PCR combination assay. J Clin Microbiol. 1996;34:2619-2622.

27. Janezic KJ, Ferry B, Hendricks EW, et al. Phenotypic and genotypic characterization of Escherichia coli isolated from untreated surface waters. Open Microbiol J. 2013;7:9-19.
28. Re R, Pellegrini N, Proteggente A, Pannala A, Yang M, Rice-Evans C. Antioxidant activity applying an improved ABTS radical cation decolorization assay. Free Radic Biol Med. 1999;26: 1231-1237.

29. Rozalska B, Wadstrom T. Interferon- $\gamma$, interleukin-1 and tumor necrosis factor- $\alpha$ synthesis during experimental murine staphylococcal infection. FEMS Immunol Med Microbiol. 1993;7:145-152.

30. Sherman BC. 2004. Magnesium Omeprazole. US Patent $6,713,495.2004$

31. Brunauer S, Emmett PH, Teller E. Adsorption of gases in multimolecular layers. J Am Chem Soc. 1938;60:309-319.

32. Sønju Clasen AB, Ruyter IE. Quantitative determination of type A and type $\mathrm{B}$ carbonate in human deciduous and permanent enamel by means of Fourier transform infrared spectrometry. Adv Dent Res. 1997;11: 523-527.

33. Pan F, Zhao X, Waigh TA, Lu JR, Miano F. Interfacial adsorption and denaturization of human milk and recombinant rice lactoferrin. Biointerphases. 2008;3:FB36-FB47.

34. Awad WA, Aschenbach JR, Zentek J. Cytotoxicity and metabolic stress induced by deoxynivalenol in the porcine intestinal IPEC-J2 cell line. J Anim Physiol Anim Nutr. 2012;96:709-716.

35. Gould IM, Bal AM. New antibiotic agents in the pipeline and how they can help overcome microbial resistance. Virulence. 2013;4:185-191.

36. Håversen L, Ohlsson BG, Hahn-Zoric M, Hanson LA, Mattsby-Baltzer I. Lactoferrin down-regulates the LPS-induced cytokine production in monocytic cells via NF-kB. Cell Immunol. 2002;220:83-95.

37. Legrand D, Elass E, Carpentier M, Mazurier J. Lactoferrin: a modulator of immune and inflammatory responses. Cell Mol Life Sci. 2005;62: 2549-2559.

38. Actor JK, Hwang SA, Kruzel ML. Lactoferrin as a natural immune modulator. Curr Pharm Des. 2009;15:1956-1973.
International Journal of Nanomedicine

\section{Publish your work in this journal}

The International Journal of Nanomedicine is an international, peerreviewed journal focusing on the application of nanotechnology in diagnostics, therapeutics, and drug delivery systems throughout the biomedical field. This journal is indexed on PubMed Central, MedLine, CAS, SciSearch $\AA$, Current Contents ${ }^{\circledR} /$ Clinical Medicine,

\section{Dovepress}

Journal Citation Reports/Science Edition, EMBase, Scopus and the Elsevier Bibliographic databases. The manuscript management system is completely online and includes a very quick and fair peer-review system, which is all easy to use. Visit http://www.dovepress.com/ testimonials.php to read real quotes from published authors. 